\title{
SOBRE A POESIA POLÍTICA DE NERUDA
}

On Neruda's political poetry

\author{
Elena Godoy*
}

$\mathrm{Q}$

uis o destino (e quiseram os organizadores deste dossiê) que coubesse a mim a parte mais delicada e mais polêmica da discussão sobre a obra de Pablo Neruda.

Devo confessar que a minha relação particular com a poesia de Neruda durante um bom tempo não foi muito feliz. Meu primeiro encontro com a obra desse poeta chileno se deu nos tempos em que cursava Letras, na antiga União Soviética, durante a última época "gelada" de um regime político que não existe mais. Tive que estudar Neruda "para passar de ano". E odiei! Só bem mais tarde, quando descobri "outros Nerudas", entendi o porquê daquele ódio. Acontece que as antologias publicadas - em espanhol! - na União Soviética se encarregaram de apresentar quase que unicamente a face mais política, mais engajada do poeta. Mesmo assim, até hoje, guardo com imenso carinho uma delas, com o prefácio de Volodia Teitelboim, presidente do Partido Comunista Chileno, na época. ${ }^{1}$

Não é esse Neruda que o mundo lembra e homenageia hoje:

En su centenario, Pablo Neruda es recordado como el poeta del amor. Pero, al mismo tiempo que apelaba al corazón de los manates,

* Universidade Federal do Paraná.

1 NERUDA, P. Veo lo que viene y lo que nace. Moscú: Progreso, 1976. 
el autor chileno entonaba un canto desesperado a quienes creían en el advenimiento de un mundo mejor, a caballo de los ideales revolucionarios que ponían en sordina las ideologías dominantes.

Assim declara Oscar Bellot no jornal virtual espanhol ABC. ${ }^{2}$

De fato, a poética do amor de Neruda ocupa um lugar importantíssimo na sua obra: Veinte sonetos de amor y una canción desesperada, Los versos del capitán, algumas de suas Odas, etc, etc, etc. Mas Neruda não seria Neruda se fosse só o poeta do amor: as poéticas nerudianas são várias, múltiplas. Algumas, inclusive, quase deixam de ser poéticas.... Em todo o caso, o que une essas tantas e diferentes poéticas, talvez, seja a sinceridade desse poeta, desse homem Neruda: "Sinceridad, en esta palabra tan modesta, tan atrasada, tan pisoteada y despreciada por el séquito resplandecente que acompaña eróticamente a la estética, está tal vez definida mi constnate acción" confessa o poeta num discurso em $1962,{ }^{3}$ como já tinha confessado em várias ocasiões anteriores. Além de ter sido um poeta do amor, ou, melhor, tendo sido um poeta do amor, Neruda certamente era um ser político. E era um poeta político. A partir da guerra civil espanhola, Neruda participa cada vez mais das lutas políticas: ingressa à Frente Popular do Chile, em 1937; é cônsul chileno para a emigração de espanhóis, em 1939; torna-se um poeta do segundo front de ajuda à Rússia, em 1942-1944; um senador comunista, em 1945; um acusador público do presidente chileno, don Gabriel González Videla; um perseguido político, enquanto termina seu Canto general, em 1948-1949, é o Prêmio Stalin da Paz, em 1950. E a lista poderia continuar.

É assim que sua posição poética também é política. "Su poesía está comprometida políticamente y debe ser juzgada también a partir de ese compromiso. Por eso, muchas controversias sobre su persona o su obra, que empiezan aparentemente como disputas estéticas, pronto desembocan en el terreno político". ${ }^{4}$

Sua viagem à Espanha em 1934, os encontros e a guerra espanhola de 1936, com o sangue inocente de suas vítimas, precipitam a conversão do poeta:

2 BELLOT, O. ABC Virtual. Disponível em: <www.abc.es> Acesso em: 04 ago. 2004.

3 NERUDA, P. Obras Completas II. Buenos Aires: Losada, 1966. p. 1102.

4 Ibid., p. 12. 
Preguntaréis: ¿Y dónde están las lilas?

¿Y la metafísica cubierta de amapolas?

¿Y la lluvia que a menudo golpeaba

sus palabras llenándolas

de agujeros y de pájaros?

Preguntaréis ¿por qué su poesía

no nos habla del sueño, de las hojas,

de los grandes volcanes de su país natal?

Venid a ver la sangre por las calles,

venid a ver

la sangre por las calles,

$¡$ ¡Venid a ver la sangre

por las calles!

(España en el corazón, 1937)

Antes de conhecer pessoalmente o socialismo e a União Soviética, Neruda, no poema La arena traicionada, do seu Canto general, já proclama o realismo socialista como sua estética - como a única estética politicamente possível:

¿Qué hicísteis vosotros, gidistas,

intelectualistas, rilkistas,

misterizantes, falsos brujos

existenciales, amapolas

surrealistas escondidas

en una tumba, europeizados

cadáveres de la moda,

pálidas lombrices del queso

capitalista...

No hicísteis nada sino la fuga,

vendísteis hacinado detritus,

buscásteis cabellos celestes,

plantas cobardes, uñas rotas,

"belleza pura", "sortilegio",

obras de pobres asustados

para evadir los ojos, para

enmarañar las delicadas

pupilas, para subsistir 
con el plato de restos sucios que os arrojaron los señores...

Essa tomada de posição custou a Neruda, já a partir de 1942, as hostilidades de Juan Ramón Jiménez, também prêmio Nobel, um poeta espanhol declarada e consagradamente "puro". Entretanto, vale a pena lembrar que era a época da ditadura de Franco, e esse repúdio à poesia "com finalidades políticas" tinha o apoio político para se preferir o discurso abstrato e metafísico. Observa Monegal ${ }^{5}$ que, para entender essa aparente "virada" na obra de Neruda, vale a pena voltar um pouco atrás no tempo e examinar mais atentamente alguns de seus textos que se situam entre Residencia e Estravagario: "Tal vez los más importantes sean los cuatro prólogos que Neruda escribió en España bajo su dirección y con el apoyo de los poetas jóvenes... Elijo el primero que se titula Sobre una poesía sin pureza:

Así sea la poesía que buscamos, gastada como por un ácido por los deberes de la mano, penetrada por el sudor y el humo, oliente a orina y azucena, salpicada por las diversas profesiones que se ejercen dentro y fuera de la ley.

Una poesía impura, como un traje, como un cuerpo, con manchas de nutrición, y actividades vergonzosas, con arrugas, observaciones, sueños, vigilias, profecías, declaraciones de amor y de odio, bestias, sacudidas, idilios, creencias políticas, negaciones, dudas, afirmaciones, impuestos. ${ }^{6}$

Paradoxalmente - ou não - é um texto verdadeira, pura e nitidamente poético publicado em outubro de 1935, oito meses antes do começo da Guerra Civil Espanhola. Além de desafiar a posição de Juan Ramón Jiménez e tantos jovens poetas que seguiam os preceitos do seu mestre, Neruda amplia, nesse manifesto, o próprio 'raio de ação' da poesia para que tudo possa ser incorporado nela: nessa estética há lugar para sonhos, profecias e declarações políticas.

Freqüentemente se critica a segunda parte do Canto general, como mais explicitamente engajada, preferindo-se sua primeira metade, aquela que celebra $55,1973$.

5 MONEGAL, E. R. Pablo Neruda: el sistema del poeta. Revista Iberoamericana, n. 39, p.

6 NERUDA, op. cit., p. 1040. 
a luta dos povos indígenas profundamente ligados à natureza americana, reivindicando, com isso, os valores e a dignidade de suas manifestações culturais. Mas, como bem lembra Melis, "es importante comprender con exactitud dónde se verifican estos momentos de debilidad y cuáles son las razones que los originan. Contrariamente a muchas liquidaciones sumarias de esta parte de la producción nerudiana, creemos que en la base de estas debilidades estilísticas hay mucho más una falta de politización que un exceso de ella". ${ }^{7}$

Em todo o caso, já em Alturas de Macchu Picchu, Neruda expressa sua conversão e seu novo credo poético:

Miradme desde el fondo de la tierra
labrador, tejedor, pastor callado:
domador de guanacos tutelares:
albañil del andamio desafiado:
aguador de las lágrimas andinas:
joyero de los dedos machacados:
agricultor temblando en la semilla:
alfarero en tu greda derramado:
traed a la copa de esta nueva vida
vuestros viejos dolores enterrados.
..............................................................
A través de la tierra juntad todos
los silenciosos labios derramados
y desde el fondo habladme toda esta larga noche,
como si yo estuviera con vosotros anclado.

A solidariedade (tão socialista?) do poeta com seus irmãos humildes está explicitamente declarada, gritada. Agora o poeta se torna um vox populi. Essa solidariedade já foi manifestada por Neruda no poema Reunión bajo las nuevas banderas de sua Tercera residencia. Em Alturas de Macchu Picchu,

hay, y esto es lo principal, el descubrimiento de un aspecto central de la vocación del poeta: a partir de este momento, por boca del poeta hablarán los hombres que no tienen voz. Por eso el poeta dirá ahora:

7 MELIS, A. Neruda y la poesía hispanoamericana. In: SCHOPF, F. Neruda comentado. Santiago de Chile: Sudamericana, 2003, p. 30. 
Yo vengo a hablar por vuestra boca muerta.

Y terminará el poema, y la secuencia entera, con este verso:

Hablad por mis palabras y mi sangre. ${ }^{8}$

Não devemos esquecer que Alturas de Macchu Picchu foram escritas em 1950, quando Neruda não só ingressa no Partido Comunista chileno, como se torna senador por esse partido. Entretanto, a "ideologia" do poema, como bem nota Monegal, "está más cerca de William Blake, de Hugo, de Whitman, que de Marx o de Lenin". ${ }^{9}$ Essa posição é contrária - e, ao meu ver, mais acertada àquela de Hermán Loyola, quem chega à conclusão de que "Digamos, en suma, que el ingreso de Neruda a las filas del Partido Comunista de Chile y la composición de Alturas de Macchu Picchu son dos expresiones gemelas de un mismo hecho interior. Ambas se explicam mutuamente y se complementan". ${ }^{10}$

Essa postura de Neruda, não tão nova assim na obra desse poeta, acompanhada de um repúdio cada vez mais violento da problemática puramente existencial, encontra, no Canto general, um certo equilíbrio, pois está contrabalanceada pela aguda relação entre uma realidade dolorosa e o espírito de luta para romper com ela. "Sólo que ahora, el don profético ascenderá a la superficie de la conciencia del poeta, se hará más explícito y hasta programático, acompañará más dócilmente la formulación ideológica del socialismo soviético. Pero en lo profundo, en la raíz, las cosas no habrán cambiado tanto, como lo demuestra una lectura profética del Canto general entero", enfatiza Monegal. ${ }^{11}$

Porém, não há como negar que toda a obra de Neruda dialoga com seu tempo. Ela é, ao mesmo tempo, uma estética, uma ética e também a praxis política.

Permitam-me agora voltar no tempo.

Um certo Neftalí Ricardo Reyes Basualto, que nasceu em uma cidadezinha chilena de Parral em 12 de julho de 1904, nunca se encontrou com um certo Aleksandr Savitski, de uma pequena cidadezinha russa. Nenhum dos dois nunca soube da existência do outro. Mas são misteriosos os fios invisíveis que unem as pessoas neste planeta!

Neftali Ricardo tinha seis meses de vida quando Aleksandr foi mandado embora do ginásio, onde estudava, por mau comportamento e por seu namoro com a política. Savitski fugiu para as florestas de Polessie e se tornou uma

8 MONEGAL, op. cit., p. 59.

9 Ibid., p. 61.

10 LOYOLA, H. Canto general: itinerário de uma escritura. Cuadernos Fundación Pablo Neruda, n. 30, p. 39, 1999.

11 MONEGAL, op. cit., p. 64. 
espécie de Robin Hood. Com um revólver nas mãos, fazia sua justiça: roubava dos ricos e entregava o dinheiro aos pobres. Em 1909, foi morto em uma batalha com os guardas. Uma página esquecida da história russa. Mas essa história romântica de Savitski fascinou tanto o grande escritor russo Leonid Andréiev que este escreveu um romance sobre suas façanhas com o título Sashka Zhegulev, que é o nome do protagonista. E o romance, por sua vez, fascinou tanto a Neftali Ricardo Reyes Basualto que este assinou seus primeiros poemas precisamente com o nome Sashka Zhegulev. Mas a seqüência de consoantes chiantes, deselegante para o ouvido hispânico, fez com que Neftali Ricardo trocasse esse pseudônimo por outro, Pablo Neruda, em homenagem ao poeta tcheco Ian Neruda (é Néruda, como soa em tcheco): afinal, tchecos ou russos são quase iguais, quando se olha de longe, da América Latina...

Durante toda a vida de Pablo Neruda, três coisas permaneceram entre tantas mudanças de paixões, desesperos, perigos e fama: a poesia, a sede de justiça e o amor à Rússia.

O amor de Neruda pela Rússia é quase um romance. Um romance nem sempre idílico e feliz, mas com alguns episódios dramáticos. A fé cega na União Soviética como representante genuíno dos ideais da humanidade, aos poucos, foi sendo substituída por uma atitude mais objetiva, mas nem por isso menos sincera e interessada. Será que ele sabia que na União Soviética nem tudo eram flores, com as quais, invariavelmente, o recepcionavam lá? Provavelmente sim. Mas era, antes de tudo, um poeta.

Em 1956, aconteceu o XX Congresso do Partido Comunista da União Soviética, no qual foram expostos os crimes de Stalin. Entre os delegados estrangeiros estavam Pablo Neruda e Jorge Amado, dois comunistas, dois fiéis amigos da União das Repúblicas Socialistas Soviéticas, a URSS. O nervosismo tomou conta de Amado. Neruda permaneceu calado. Ao voltar ao Brasil, Jorge Amado rompeu com o Partido Comunista Brasileiro. Neruda permaneceu e morreu comunista.

Provavelmente o livro mais comprometido com a doutrina do realismo socialista é precisamente Las uvas y el viento, publicado em 1954. O livro foi escrito entre 1950 e 1953, mas o poeta começa a concebê-lo já em 1949. Em junho desse ano, depois de ter participado do Congresso Mundial de Partidários da Paz em Paris, Neruda chega pela primeira vez a Moscou, convidado pela União dos Escritores Soviéticos para participar da celebração do $150^{\circ}$ aniversário do nascimento do poeta russo Alexandr Pushkin. Em 1950, Pablo Neruda recebeu, em Moscou, o Prêmio Internacional Lenin "Pela paz entre os povos".

Entre junho de 1950 e agosto de 1952, Neruda percorreu milhares e milhares de quilômetros de avião, de trem, de carro: Praga, Paris, Roma, Nova Déli, Varsóvia, 
Florença, Torino, Gênova, de novo Roma, Milão, de novo Paris, de novo Moscou e Praga. Chega a Berlin para participar do Festival Mundial da Juventude. Segue a Bucareste. Faz uma viagem através de quase toda a União Soviética pela Transsiberiana com destino a Pequim, Mongólia. De novo Europa: Praga, Suíça, Itália (Capri).

Observa Romera ${ }^{12}$ que "Neruda, al enunciarse como un yo poeta a lo largo de sua obra, contribuye a que su poesía sea identificada con los episodios reales de la vida del autor". Porém, foi o próprio Neruda que comentou sobre sua perspectiva poética de testemunha-cronista:

El poeta debe ser, parcialmente, el CRONISTA de su época. La crónica no debe ser quintaesenciada, ni refinada, ni cultivista (...) y muy difícil fue para mí llegar al arrastrado prosaísmo de ciertos fragmentos del Canto general (...) Porque así escribe el cronista. Las uvas y el viento, que viene después, quiso ser un poema de contenido geográfico y poético (...) Su vastedad y su inevitable apasionamiento político lo hacen difícil de aceptar a muchos de mis lectores. Yo me sentí feliz escribiendo este libro.

E acrescentou: "Quiero que este canto sea mi contribución a la paz. Quiero que este canto reúna esta unidad amenazada: nuestro mundo de hoy. Porque los poetas tenemos también un deber supremo y es el de contribuir a la paz del mundo. La incultura es guerra. La paz es cultura." ${ }^{13}$ É assim que o poeta propõe pôr em prática a poética e a política.

O ciclo é concebido como um canto e é estruturado como uma viagem. Já no prólogo, o poeta, a partir do título Tenéis que oirme, se anuncia um rapsoda (tenéis como mirad e hablad do Canto general: segunda pessoa do plural é uma forma inusual, arcaica na América Hispânica e, portanto, soa mais solene), que canta, errante, como os antigos rapsodas gregos:

12 ROMERA, L. Neruda y el signo de su poesía. Prólogo a Las uvas y el viento. Buenos Aires: Sudamericana, 2003. p. 7.

13 Ibid., p. 15. 


\author{
Yo fui cantando errante \\ entre las uvas \\ de europa \\ y bajo el viento, \\ bajo el viento en el asia. \\ Lo mejor de las vidas \\ y la vida, la dulzura terrestre, \\ la paz pura, \\ fui recogiendo, errante, \\ recogiendo
}

Os paralelismos e as reiterações, os procedimentos tão queridos de Neruda, vão nos guiando ritmicamente às razões desse canto, a sua dimensão ética e moral. E o poeta aqui "recolhe" o sentido da vida que canta a experiência de um sujeito ativo. A poética de Neruda, nesse ciclo, alterna o discurso intimista e o celebratório. Cada espaço percorrido é cantado em um registro diferente, como na épica antiga: a Europa milenar recebe um tom intimista, se atendo ao referente estético; já a Europa Oriental e a Ásia são cantadas em um registro mais pomposo, de ode, também de acordo com seus referentes históricos e políticos.

Nesse ciclo, o poeta se propõe a cantar o novo mundo que conhece em suas visitas durante o exílio. Mas Neruda não só exalta a Rússia, a China, a Polônia, a Mongólia, a Tchecoslováquia e a Hungria, suas conquistas e sua gente; ele não poupa veneno e tintas negras, ao pintar os países capitalistas e, sobretudo, os Estados Unidos, seus chefes civís e militares, sua política, seu regime e seu modo de ser e de viver. E é nessa obra que o poeta chileno paga tributo não apenas e simplesmente ao realismo socialista, como mais precisamente às teorizações de Zhdanov ${ }^{14}$ sobre arte e literatura, nas quais este anunciava $\mathrm{o}$ fim dos conflitos de classe na União Soviética e profetizava os futuros conflitos mundiais. Muito de acordo com as idéias de Stalin a respeito.

Mas o quê é o tão falado realismo socialista?

14 Andrei Aleksandrovitch Zhdanov (1896-1948) foi um destacado funcionário do governo e ideólogo do Partido Comunista soviético. Sempre lutou contra o "surgimento de novas idéias e de influências estrangeiras que minam o espírito do comunismo". Criticou ferozmente a poesia de A. Ahmatova, os filmes de S. Eisenshtein, V. Pudovkin e outros, condenou como "formalista e antipopular" a obra dos compositores S. Prokofiev e D. Shostakovitch. Entendia a arte e a cultura como os "motores" da educação e da propaganda política. No congresso de escritores soviéticos, em 1934, define o conceito de realismo socialista e delineia a tarefa da literatura como o "serviço ao povo, à causa do partido de LeninStalin, à causa do socialismo". 
O surgimento do realismo socialista remonta ao ano 1918 (um ano depois da revolução - que hoje se prefere chamar de golpe - bolchevique), quando o Comitê Central do Partido Social-Democrata (posteriormente renomeado de Comunista) russo chamou os artistas a criar uma arte realista de propaganda socialista, acessível às grandes massas. Em 1920, o jornal comunista Pravda dedica páginas e páginas aos ataques às "invenções abstratas inspiradas pela pequena burguesia”. Em 1922, foi criada a Associação dos Pintores da Rússia Revolucionária inspirada nas teorizações de M. Gorki, quem proclamou como tarefa da arte apresentar, de maneira "artística e ao mesmo tempo documental" o triunfo das realizações da revolução. Dessa maneira, numa obra de arte, o que deve adquirir maior relevância é tão somente a temática específica: o "conteúdo" predomina sobre a "forma".

Nas palavras do escultor russo Ernst Neizvestny, o autor do famoso e imenso baixo-relevo da barragem de Assuã, no Egito, entre outras obras,

nesse reino da burocracia, onde o burocrata se tornou poeta, e o poeta, um burocrata (...) se vivia no mundo do realismo socialista, i.e., no mundo da propaganda por eles criada, da propaganda que eles declararam realidade (...) Eles realmente viviam no mundo fantástico do "realismo socialista", onde já não era mais possível separar o fato da ficção, a informação da desinformação. A ideologia negava que algum fenômeno pudesse ser apenas 'humano', inclusive o sentido das palavras: não poderia haver simplesmente uma "realidade" e muito menos um "realismo". A realidade podia ser ou "burguesa", ou "socialista" (...) Tanto para as autoridades superiores, como para os criadores do mundo virtual do realismo socialista, o 'real' era o que tinha sido dito pelo partido. ${ }^{15}$

A pintura, a literatura e até a música se dedicam aos louvores da vida cotidiana - invariavelmente feliz - dos camponeses e dos proletários, às façanhas dos soldados de aço defensores da revolução e, sobretudo, aos inúmeros retratos dos sábios líderes do Partido... Todos heróis, "comunistas até a medula" (cliché usado e repetido até a exaustão), destemidos e assexuados... Em outras palavras,

15 NEIZVESTNY, E. Katakombnaia kultura i ofitsialnoie iskusstvo ("A cultura das catacumbas e a arte oficial”). Posiev, n. 11, 1979. Disponível em: <www.belousenkolib.narod.ru/Actors/Neizvestny> Tradução minha - EG. 
a tarefa do artista se resume em servir o mais fielmente possível aos ideais do Partido Comunista, à luta de classes, e em colaborar com a construção do socialismo. As obras mais aplaudidas e premiadas da época, além de repetitivas, chegam a beirar o panfletário, desafiando qualquer concepção da estética.

Vale lembrar que a doutrina imperou até os anos da Perestroika, e ai daqueles que teimaram em não segui-la...

O comprometimento de Neruda com o realismo socialista se dá exatamente quando o poeta celebra seu $50^{\circ}$ aniversário e está no auge de sua fama. Neruda percorre o mundo com os olhos abertos pela esperança, com os braços abertos pela solidariedade e o coração aberto ao calor da vida e dos sentimentos humanos. Mas a voz do poeta que se elevou à perfeição nos poemas do Canto general, que, no ciclo Las uvas y el viento, canta as vinhas da Itália (La túnica verde), as cigarras da China (El viento en Asia), descobre o sabor da primavera na Polônia (Regresó la sirena), que revela seu secreto amor em Capri (Nostalgias y regresos), essa mesma voz doce e viril é trivializada ao insultar os "inimigos" e se infantiliza ao exaltar as conquistas do socialismo e as virtudes dos seus chefes, chegando ao ridículo, ao descuído e ao prosaísmo irritantes aos ouvidos do leitor menos comprometido com os preceitos do "realismo socialista".

Um dos chef d'oeuvres dessa natureza é o poema La ciudad herida que, em seus 110 versos, pinta, declaradamente em preto e branco, sem se preocupar com a existência de quaisquer outras cores ou matizes, a cidade de Berlim:

\author{
El resplandor del tiempo \\ como un relámpago en berlin del este \\ iluminaba el paso \\ de los jóvenes libres \\ que levantaban la ciudad de nuevo. \\ En la sombra pasé de lado a lado \\ y la tristeza de una edad antigua \\ me llenó el corazón como una pala \\ cargada de inmundicia. \\ En Berlín custodiaba el Occidente \\ su "libertad" inmunda, \\ y allí también estaba \\ la estatua con su falso \\ fanal, su mascarón leproso \\ pintado de alcohólico carmín,
}




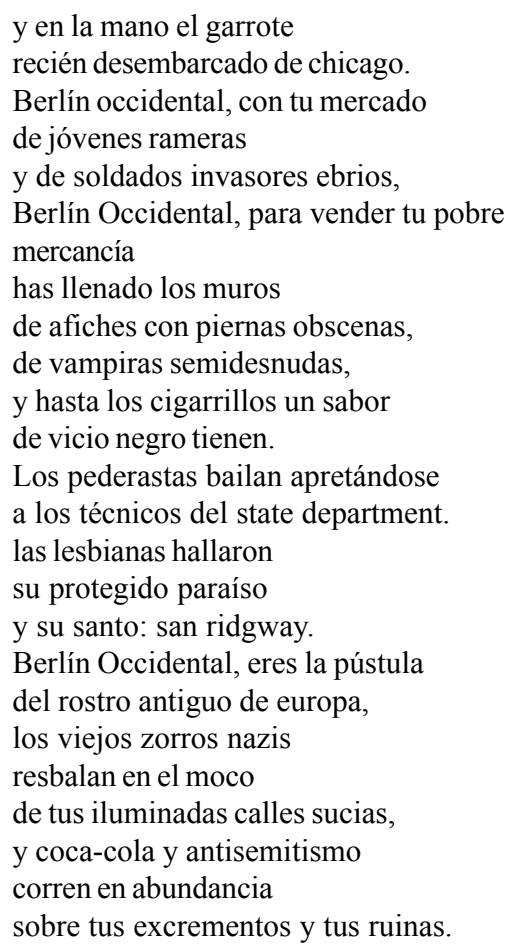

O habitual verso livre de Neruda auxiliado por cortes e encavalgamentos despeja as "imundícies", quase se delicia com elas, repetindo o "tema com variações": inmundicia, inmunda, mocos, excrementos, leproso, ebrios, vicio negro. Apesar de existirem ruas iluminadas, o poeta habilmente cria sinestesias e deixa seu leitor na total escuridão, asfixiado com o odor dos excrementos e deslizando em mocos. E que criaturas habitam esse mundo fantástico, mergulhado na sombra e na tristeza? Nesse mundo virtual (inventado e acreditado pelo poeta!), não há pessoas alegres, felizes, nem mesmo inocentes, ingênuas ou honestas. Ninguém assa o pão, ninguém varre as ruas, ninguém sorri para as crianças... Por aqui desfilam personagens em forma de pecados (ou preconceitos?): rameras, vampiras, soldados invasores ebrios, pederastas, lesbianas, viejos zorros nazis... 
Depois de cantados em detalhes os defeitos, os pecados e as porcarias de Berlim Ocidental, vem a última parte do poema:

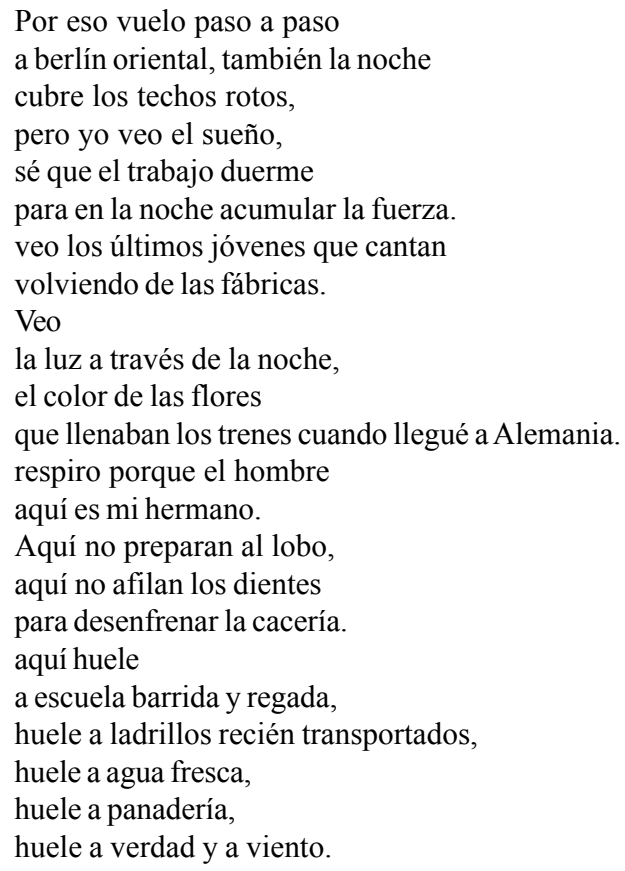

É simples: lá é a decadência; aqui, a renovação. Lá, os pecados, aqui, as virtudes. Lá, a escuridão; aqui, a luz. Lá, o negro; aqui, o branco. Tal qual em qualquer livrinho de iniciação ao materialismo histórico da época: o imperialismo putrefato e agonizante versus o "novo homem" e a aurora do comunismo. Simples. E o nosso poeta medita sobre os regimes políticos, andando: pasé de lado a lado, vuelo paso a paso. Simples. Esquecendo de quantos pereceram, tentando passar de lado a lado... É o mundo virtual do "realismo socialista".

De volta ao Chile em 1953, em sua casa na Isla Negra, Neruda recebe a notícia sobre a morte de Stalin e escreve um longo poema En su muerte publicado no mesmo ciclo Las uvas y el viento. O poema, que é uma elegia (um llanto, um 
responso, como se diria tradicionalmente em espanhol), um gênero tão profundamente hispânico, é quase uma narração, escrita claramente por um Neruda ex-senador comunista, perseguido pelo regime de seu próprio país e ganhador do Prêmio Stalin da Paz:

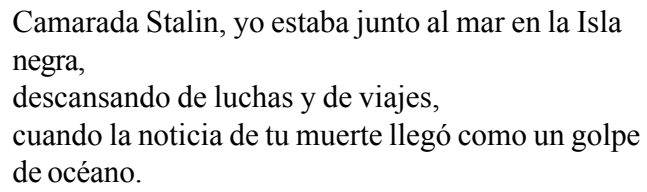

A seguir, a primeira parte do poema conta a história do imperialismo do começo do século XX e da Revolução Russa. Violentando o melhor da poética nerudiana, o poema é um quadro quase ingênuo sobre os bandidos e os mocinhos, pintado em duas cores: o preto - para os "maus" e o branco (ou seria melhor dizer o vermelho?), para os "bons":

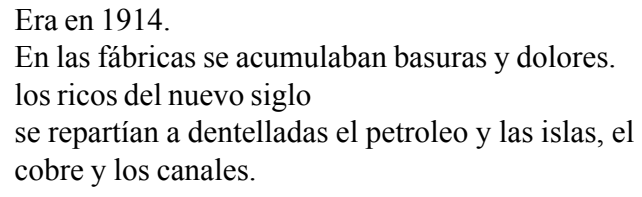

Frenético era el baile de los gringos en las boîtes de parís llenas de humo.
Allí estaban sentados
de frac, ocupadísimos
en dispensarse condecoraciones,
en regalarse cheques a la entrada
y robárselos a la salida,
en regalarse acciones de la carnicería
y repartirse a dentelladas
trozos del pueblo y de geografía. 
E segue a narrativa, mais prosaica do que nunca, para anunciar a entrada em cena dos "mocinhos":

\author{
Entonces con modesto \\ vestido y gorra obrera, \\ entró el viento, \\ entró el viento del pueblo. \\ Era Lenin. \\ Cambió la tierra, el hombre, la vida. \\ El aire libre revolucionario \\ trastornó los papeles \\ manchados. Nació una patria \\ que no ha dejado de crecer. \\ Es grande como el mundo, pero cabe \\ hasta en el corazón del más \\ pequeño \\ trabajador de usina o de oficina, \\ de agricultura o barco. \\ Era la Unión Soviética.
}

E aparece o "herói" que traz a felicidade para as massas, um "mocinho" do happy end: grandioso, mas ao mesmo tempo modesto (sem esquecer a gorra gris de obrero solidária com a gorra obrera de Lenin) e sem uma única mancha no seu retrato de um monumento imortal revolucionário que entró en la História. Aqui é preciso abrir os parênteses para dizer que essa "História" é contada com uma tremenda parcialidade: Lenin não recibió de los zares telarañas y harapos. Rússia, apesar de todos os defeitos e erros dos governos czaristas, era uma das maiores potências do mundo. Maior do que é agora, depois dos 70 anos do socialismo leninista-stalinista e etc.! Os "feitos" de Stalin, como se sabe (sabia disso Neruda?!), as grandes construções dos novos centros industriais no Norte do país e dos fabulosos canais entre os rios Volga e Don, as grandiosas realizações do socialismo foram obra das mãos dos milhões e milhões de presos, acusados de crimes não cometidos em poucos minutos de "julgamentos" sem direito a qualquer defesa, precedidos de dias e semanas de torturas... A Rússia sob o poder de Stalin tinha se tornado uma multidão de cidadãos presos no seu país, condenados a trabalhos forçados mesmo sem acusações e julgamentos... Mas, claro, Neruda não era um historiador e estamos analisando um poema e não um tratado de história.

Eis esse retrato cem por cento "realista socialista": 


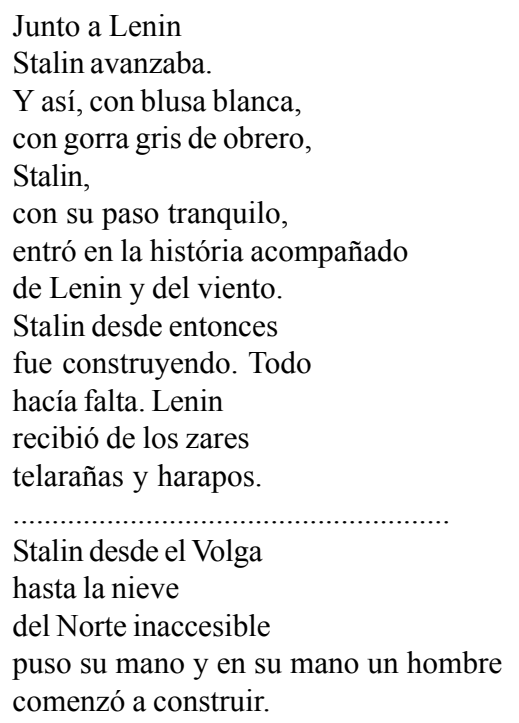

$\mathrm{O}$ verso de Neruda é curto e muito firme, embora irregular. O nome de Stalin (ao contrário do nome de Lenin) invariavelmente aparece no começo do verso, marcando a importância da personagem. Na seqüência, aparecem os versosmarteladas, versos curtíssimos de uma palavra (com duas exceções de versos de três palavras - curtas), que imortalizam os feitos heróicos, para terminar a estrofe, envolvendo em versos mais longos e suaves o eu poético e o leitor na admiração de uma (sobre) humana simplicidade do herói:

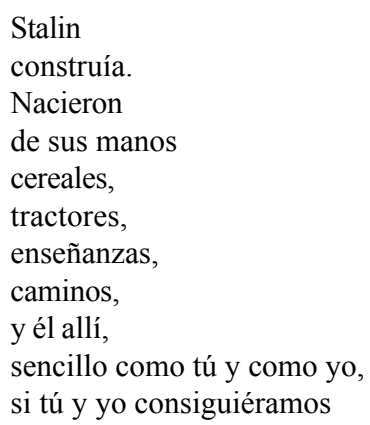


ser sencillos como él.

O panegírico realista-socialista continua, sempre em versos curtos e marcados como os passos dos soldados do exército comunista:

\author{
¡Ser hombres! ¡Es esta \\ la ley staliniana! \\ Ser comunista es difícil. \\ Hay que aprender a serlo. \\ Ser hombres comunistas \\ es aún más difícil, \\ y hay que aprender de Stalin...
}

A estrofe que segue é digna de ocupar a primeira página do jornal Pravda. Em versos longos (graves, se diria em espanhol), eleva-se a voz do eu poético em um crescendo marcado por exclamações, clamando a todos a se tornarem "stalinianos" - adjetivo que se reitera, abrindo e fechando os versos - e a marcharem sob as bandeiras comunistas:

Stalinianos. Llevamos este nombre con orgullo.

Stalinianos. ¡Es ésta la jerarquía de nuestro tiempo!

¡Trabajadores, pescadores, músicos stalinianos!

¡Médicos, calicheros, poetas stalinianos!

¡Letrados, estudiantes, campesinos stalinianos!

¡Obreros, empleados, mujeres stalianas,

salud en este día!

O poema termina na melhor das tradições do otimismo realista-socialista (ou, seria melhor dizer: do realismo maravilhoso?): um "simples proletário" do longínquo Chile, um representante do povo (mirando... con los viejos ojos del pueblo), aparece para assegurar ao poeta e ao mundo que a causa estalinista não morrerá e que os herdeiros do grande chefe, encabeçados por um tal de Malenkov, o braço direito do finado chefe (muito bem informado quanto aos rumos da política soviética e internacional esse proletário!), continuarão firmes: 
Más tarde el pescador de erizos, el viejo buzo

Y poeta,

Gonzalito, se acercó a acompañarme bajo la bandera.

"Era más sabio que todos los hombres juntos", me dijo mirando al mar con sus viejos ojos, con los viejos

ojo del pueblo.

Y luego por largo rato no nos dijimos nada.

Una ola

Estremeció las piedras de la orilla.

"Pero Malenkov ahora continuará su obra", prosiguió

levantándose el pobre pescador de chaqueta raída.

Um Stalin muito diferente aparece em um dos poemas do ciclo Memorial de la Isla Negra (1964): é a imagem de um ditador - morto para sempre? um morto-vivo? - multiplicada por milhares de monumentos em milhares de cidades russas e européias, que vislumbra o eu lírico de Neruda agora livre do servillismo realista:

Siempre en aquellas estatuas estucadas
de bigotudo dios con botas puestas
y aquellos pantalones impecables
que planchó el servillismo realista.
a................................................................
aquella efigie fría de un distante:
de un ser que, entre uno y otro movimiento,
se quedó inmóvil, muerto en la victoria.
Y aquel muerto regía la crueldad
desde su propia estatua innumerable:
aquel inmóvil gobernó la vida.

Com a reiteração dos demonstrativos aquellas/aquellos/aquella/aquel Neruda marca a distância temporal e espacial: é passado, é longe, é un distante que "foi", se quedó inmóvil. O eu poético se afasta do personagem: foi uma estátua que governou a vida com crueldade. Mas vejamos um detalhe: essas estátuas inumeráveis do governante que se foi não são estátuas de mármore ou de bronze. Não. São estátuas "estucadas", baratas. Esse é o valor do "imperador" e do "império", como o entende o poeta agora. Sem o mínimo de rodeios, Neruda fala abertamente da crueldade daquele governo e usa o adjetivo extremamente 
cotidiano bigotudo que se choca com o substantivo dios que o governante pretendia ser ou que pretendiam que ele fosse. "El servillismo realista" (um belíssimo jogo com o "realismo socialista"), diz o poeta, "planchó los pantalones", para não dizer (ou dizendo mesmo!) que beijava as botas, as calças e outras coisas menos pronunciáveis. Pelo menos em um poema.

O tema que me foi proposto é a poesia "engajada" de Pablo Neruda: uma das tantas facetas da imensa obra desse poeta. Uma sinfonia polifônica (como costuma ser uma verdadeira sinfonia) em que se alternam ritmos, versos, temas, vozes, imagens: umas pintadas com as duras pinceladas de tintas pretas e brancas; outras são finas aquarelas de metáforas deliciosamente nerudianas... Este é o canto épico e lírico da viagem poética de um rapsoda errante.

Pablo Neruda viveu 69 anos e, destes, escreveu poesia durante 55. Escreveu sobre tudo que lhe tocava. E talvez pudesse fazer sua a sentença de Terêncio: ${ }^{16}$ "Sou homem e nada do que é humano me é alheio".

16 Públio Terêncio Afer (19 ou 185-159 a.C.). Dramaturgo romano. Nasceu em Cartago, foi escravo do senador romano Públio Terêncio Lucano, obtendo posteriormente a liberdade. 


\title{
RESUMO
}

Este trabalho discute a chamada "poesia engajada" de Pablo Neruda bem como sua relação com o realismo socialista. Focalizam-se alguns poemas mais polêmicos de seu ciclo Las uvas y el viento, com o objetivo de refletir sobre seu lugar na obra do poeta chileno e seu papel no contexto histórico-político mais amplo.

Palavras-chave: poesia hispano-americana, Pablo Neruda, literatura engajada.

\section{RESUMEN}

Este trabajo discute la así llamada "poesía compromisada" de Pablo Neruda y su relación con el realismo socialista. Se enfocan algunos poemas más polémicos de su ciclo Las uvas y el viento, teniéndose como el alvo la reflexión sobre su lugar en la obra del poeta chileno y también su papel en el contexto histórico-político más amplio..

Palabras-clave: poesía hispanoamericana, Pablo Neruda, literatura compromisada.

\begin{abstract}
This paper discusses the type of poetry that is called "politically engaged"("poesía compromisada") by Pablo Neruda as well as its relationship with socialist realism. Some of his most controversial poems from the cycle Las uvas y el viento will be focused with the goal of reflecting about its place on the Chilean poet's works and its importance in a wider historic political context.

Key-words: Latin American poetry, Pablo Neruda, political poetry.
\end{abstract}

\section{REFERÊNCIAS}

Obs.: Não incluí deliberadamente as referências bibliográficas das obras poéticas de Neruda citadas neste texto, pois existem inúmeras edições e, neste caso, não foi meu objetivo comparar e/ou analisar as versões publicadas.

BELlOT, O. ABC Virtual. Disponível em: <www.abc.es> Acesso em: 4 ago. 2004.

LOYOLA, H. Canto General: itinerario de una escritura. Cuadernos Fundación Pablo Neruda, n. 3, p. 36-42, 1999. 
MELIS, A. Neruda y la poesía hispanoamericana. In: SCHOPF, F. Neruda comentado. Santiago de Chile: Sudamericana, 2003.

MONEGAL, E. R. Pablo Neruda: el sistema del poeta. Revista Iberoamericana, n. 39, p. 41$71,1973$.

NEIZVESTNY, E. Katakombnaia kultura i ofitsialnoie iskusstvo ("A cultura das catacumbas e a arte oficial'). Posiev, n. 11, 1979. Disponível em: <www.belousenkolib.narod.ru/Actors/ Neizvestny>

NERUDA, P. Prólogo. Caballo verde para la poesía. Madrid: [s.n.], 1935.

Obras completas. Buenos Aires: Losada, 1966.

Veo lo que viene y lo que nace. Moscú: Progreso, 1976.

REVISTA CULTURAL. Disponível em: <www.vor.ru/Spanish/Revista/rev-4.html>

ROMERA, L. Neruda y el signo de la poesía. Prólogo a Las uvas y el viento. Buenos Aires: Sudamericana, 2003.

SCHOPF, F. Neruda comentado. Santiago de Chile: Sudamericana, 2003. 